\title{
GEOCHEMICAL STUDIES ON THE MANGROVE REGION OF CANANÉIA, BRAZIL. II. PHYSICO-CHEMICAL OBSERVATIONS ON THE REDUCTION STATES
}

\author{
(Received for publication in 1959)
}

\author{
KenJI Kato * \\ Faculty of Fisheries, Hokkaido University - Japan \\ Oceanographic Institute, University of São Paulo - Brazil
}

\begin{abstract}
SYNOPSIS
This paper deals with the study that was done to show the peculiar biogeochemical reduction process which occurs in the river Nóbrega, one of the "marigots" from the Cananéia lagoon, State of São Paulo, Brazil.
\end{abstract}

\section{INTRODUCTION}

The water in the channels or "marigots" which occur in the mangrove region such as the lagoon of Cananéia (State of São Paulo - Brazil) show peculiar geochemical characteristics caused chiefly by a state of reduction. This state, prevailing in the brackish water of the channels, is important as an ecological and as a geochemical factor, since it can alter the chemical structure of the water causing the exchange of elements and also altering the sediments.

The oxidation-reduction process has two attributes: intensity and capacity. Intensity is expressed by the potential and the capacity is the poising of the system or the maintaining of the same intensity, while undergoing a certain amount of oxidation-reduction, analogous to the phenomenon of the buffering capacity, depending on the hydrogenion concentration of a solution. The oxidation-reduction potential, or the "redox-potential" indicates the intensity of the corresponding oxidation-reduction condition. It is generally expressed in volts relatively to the normal hydrogen electrode. Although considerable work has been done on the redox potentials in living organisms, little is known about the conditions in the water (ZoBell, 1946; Nomura \& YAMADA, 1941).

The purpose of this paper is to study the peculiar process of geobiochemical reduction which occurs in the "marigot". Physico-chemical observations were carried out in the channel of river Nóbrega, one of the "marigots" in the Cananéia Lagoon, during the periods 18-19 January, 26-27 March and 25-26 April 1958. The results obtained chiefly in March are those presented in this paper.

\section{METHODS AND DATA}

The measurements of the redox potential of the water was made by the Portable Metrohm Potentio.

- At present in the Faculty of Fisheries, Prefectural University of Mie, Tsu, Japan. meter (Glass-electrode PH-meter). The combined platinum and $\mathrm{AgCl}$ electrode, attached to the instrument, was inspected carefully and tested in the standard redox system before being used for measuring the Eh of the unknown redox systems. A solution of $\mathrm{M} / 300 \mathrm{~K}_{3} \mathrm{Fe}(\mathrm{FN})_{6}$ and $\mathrm{M} / 300 \mathrm{~K}_{4} \mathrm{Fe}(\mathrm{CN})_{6}$ in $\mathrm{M} / 10 \mathrm{KCl}$, which has an $\mathrm{Eh}$ value of +0.430 volt at $25^{\circ} \mathrm{C}$, is a stable, readily prepared standard redox system.

Water samples were collected at various depths from the boat by using a simple syphonic watersampler designed by the author. Figure 1 shows the position of the stations in the "marigot" studied. As soon as collected the water sample was immediately submitted to the measurements of the redox-potential and of the $\mathrm{pH}$. The results of the observations are given in Table $\mathrm{I}$, and illustrated in a series of figures (Figs. 2-5).

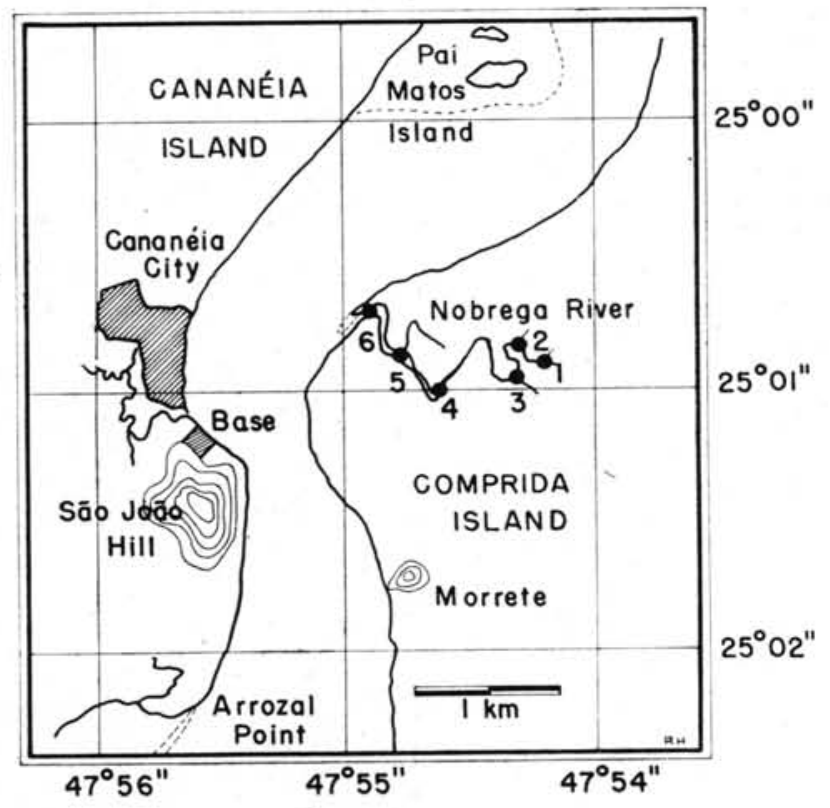

Fig. 1 - Chart showing collecting stations. 


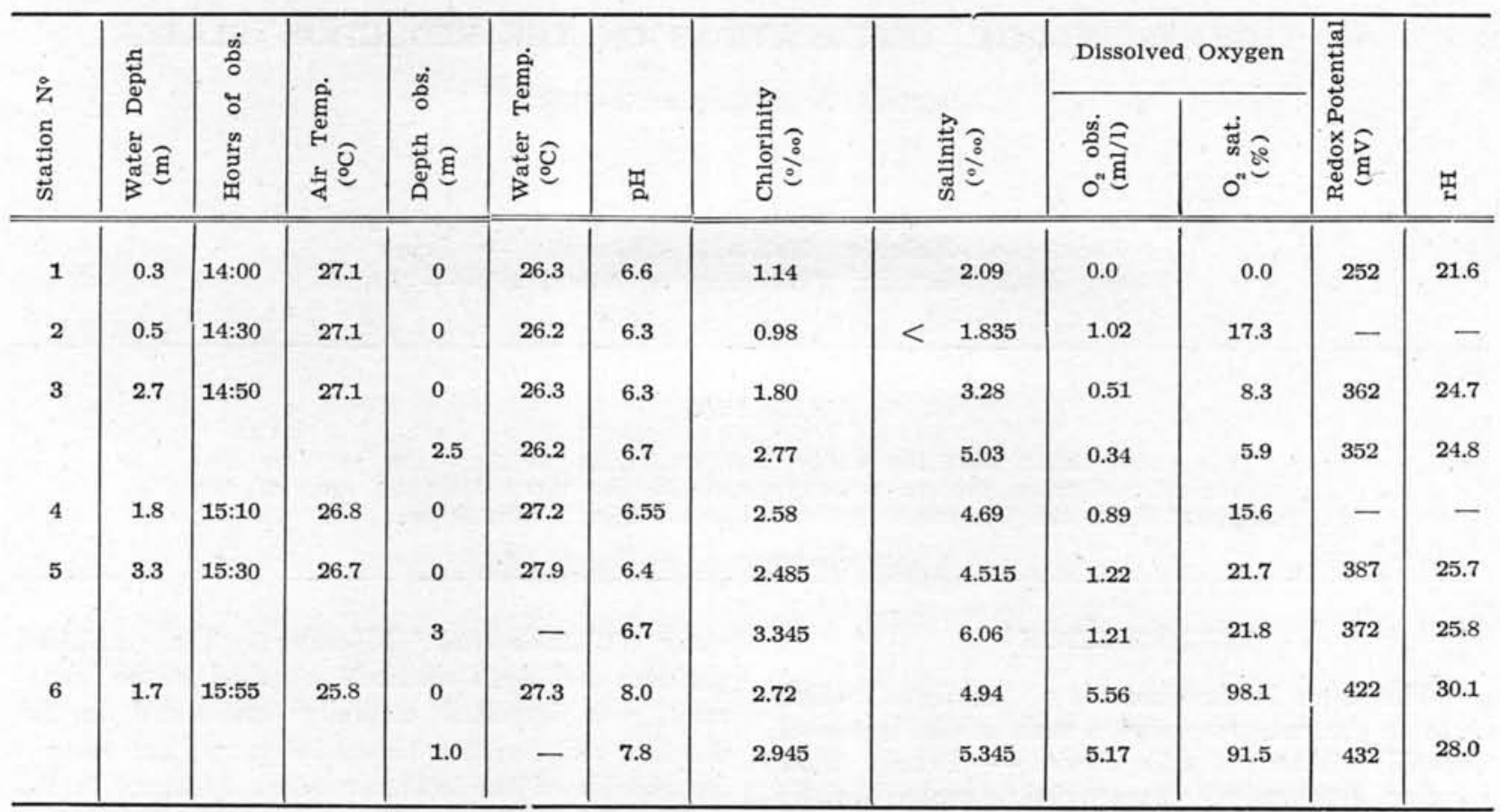

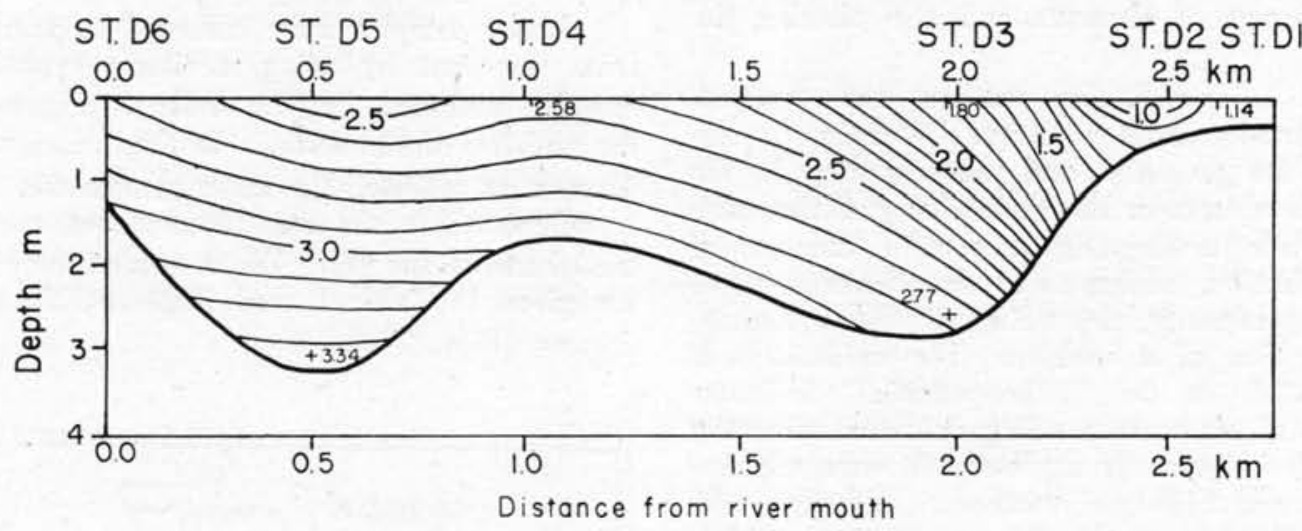

Fig. 2 - Chlorinity in Nóbrega river $(\%)$.

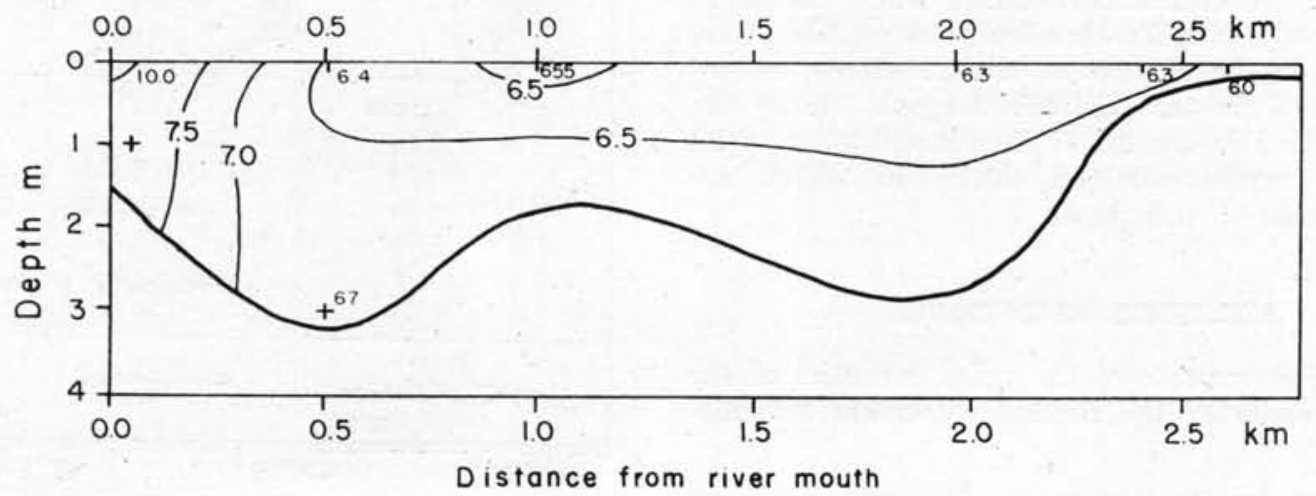

Fig. $3-\mathrm{pH}$ in Nóbrega river. 


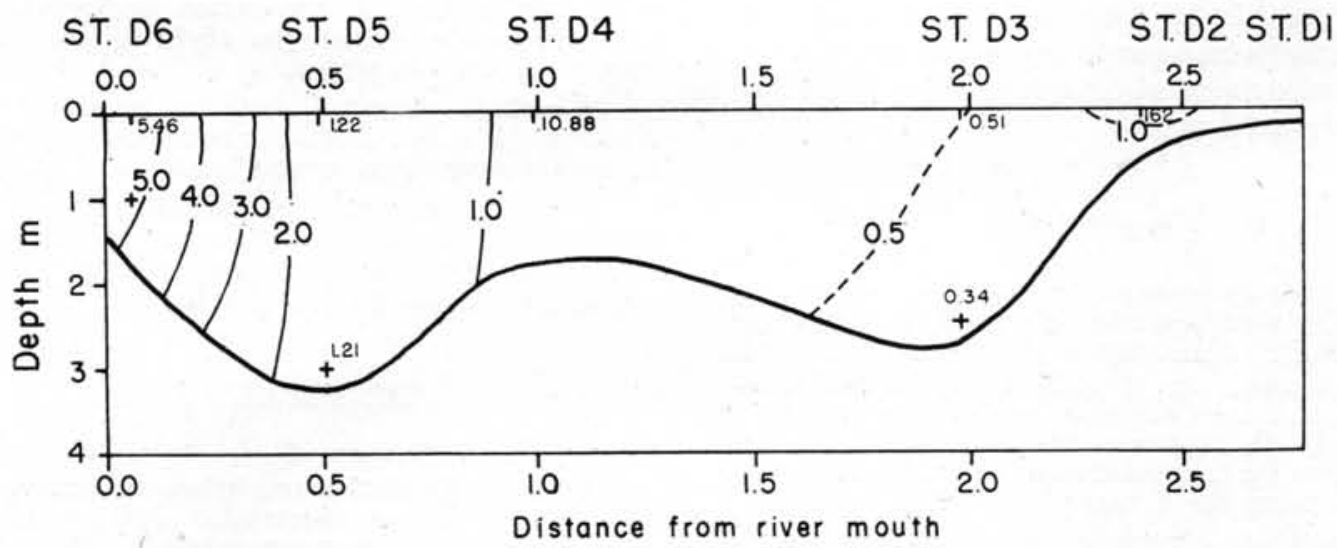

Fig. 4 - Dissolved oxygen in Nóbrega river $(\mathrm{ml} / 1)$.

Chlorinity distribution (Fig. 2) showed that saline water, approximately with $2.3-3.0 \% \mathrm{Cl}$ reached the bottom layer of St. D-3 poised in relation to the fresh-water with $1.0 \% \mathrm{Cl}$ or less, in the upper reaches of the mangrove channel. The other properties like $\mathrm{pH}$ and dissolved oxygen gave more or less characteristic features in their distribution. As illustrated in Figure 3 , the surface water had generally a lower $\mathrm{pH}$ value, about 6.5 while at the mouth of the mangrove channel the $\mathrm{pH}$ value was higher (8.0). The oxygen content of the water decreased towards the upper reaches of the channel and finally a characteristic zone with no oxygen in the water was observed at St. D-1. Distribution of the redox potential of the water showed features analogous to the oxygen content (Fig. 5), namely $430 \mathrm{mV}$ in the outer water and $250 \mathrm{mV}$ in the interior water.

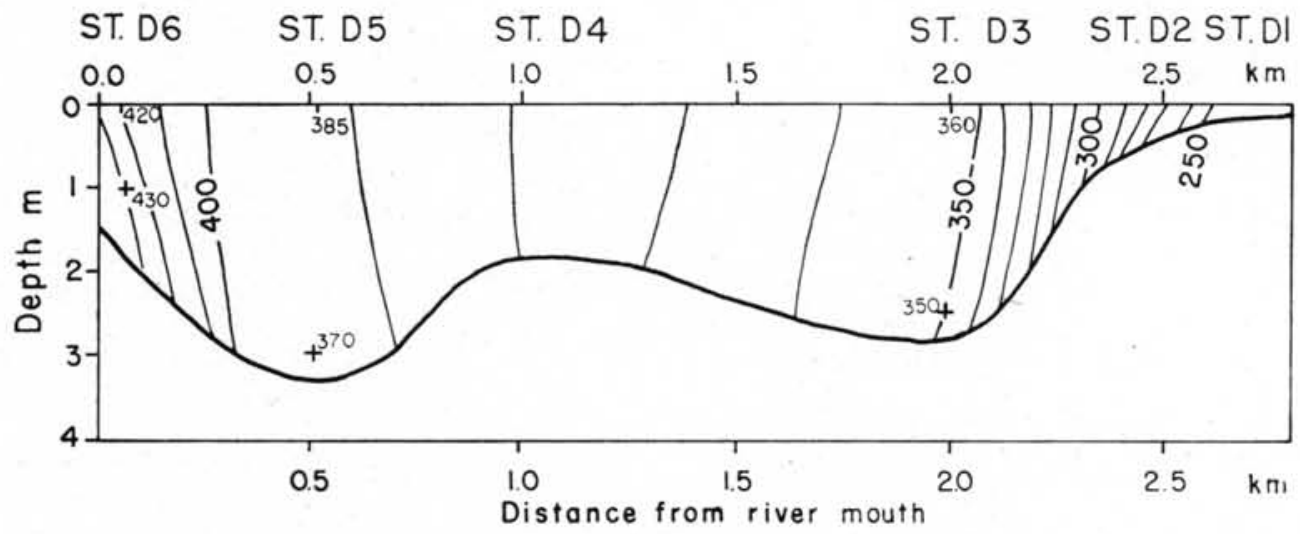

Fig. 5 - Redox potential in Nóbrega river $(\mathrm{mV})$.

TABLE II

\begin{tabular}{|c|c|c|}
\hline SYSTEM & $\mathrm{rH}$ & $\begin{array}{l}\text { E。 } \\
\text { volt }\end{array}$ \\
\hline Oxygen electrode (theoretical) & 41.0 & +0.810 \\
\hline Phenol blue chloride & 21.6 & +0.227 \\
\hline Methylene blue & 14.4 & +0.011 \\
\hline Indigo disulphonate & 9.9 & -0.125 \\
\hline $\begin{array}{l}\text { Hydrogen electrode (theore- } \\
\text { tical) }\end{array}$ & 0.0 & -0.421 \\
\hline
\end{tabular}

\section{CONCLUSION}

The most notable fact observed in this study is the active decomposition of organic matter by bacterial which causes a remarkable depletion of dissolved oxygen and a characteristic depression of the redox potential of the "marigot" waters.

The low value of the $\mathrm{pH}$, as shown before, is probably due either to the dissolved organic acids, as for instance, tannic acid from the mangrove trees or to the presence of other acids produced by the biochemical processes involved in bacterial decomposition, or to all such factors. Thus, the characteristic reduction that occurs in the "marigot" will no doubt limit the development of aquatic organisms 
in the region. It is important to determine the relationships between aquatic organisms and the "marigot's" physico-chemical characteristics, which still remain vastly unknown.

\section{RESUMO}

A finalidade do presente estudo é mostrar o processo peculiar geobioquímico de redução que ocorre nos "marigots". Observações físico-químicas foram realizadas no canal do rio Nóbrega, um dos "marigots" da laguna de Cananéia, nos periodos 18-19 de janeiro, 26-27 de março e 25-26 de abril de 1958. Neste estudo são apresentados os resultados referentes principalmente a março.

Foi constatada decomposição de matéria orgânica por ação bacteriana, a qual motiva a queda do teor de oxigênio dissolvido, bem como a característica depressão do potencial de óxido-redução das águas dos "marigots".

O valor baixo do $\mathrm{pH}$ constatado é devido, provàvelmente, à presença de ácidos orgânicos dissol- vidos (ácido tânico), ou outros ácidos provindos da ação bacteriana, ou mesmo ainda da combinação dos vários fatôres discutidos.

A redução característica das águas do "marigot", sem dúvida, é um fator limitante do desenvolvimento de organismos vivos nessas regiőes.

Ainda permanecem desconhecidas as relações entre organismos vivos e as características físico-químicas das águas dos "marigots"; nesse particular os estudos se fazem muito importantes.

\section{R E F E R E N C E S}

Nomura, S. \& YAMADA, N.

1941. Oxidation-reduction potentials of some bottom materials. Jubilee publication in the Commemoration of Prof. H. Yabe's $60^{\text {th }}$ Birthday, p. 1195-1212.

ZoBell, C. E.

1946. Studies on redox potential of marine sediments. Bull. Am. Ass. Petrol. Geol., vol. 30, n. $^{\circ} 4$, p. $477-513$. 